\title{
The influence of black locust (Robinia pseudoacacia) flower and leaf fall on soil phosphate
}

\author{
Yong Chul Lee • Jong Min Nam • Jae Geun Kim
}

Received: 21 January 2010 /Accepted: 1 November 2010 /Published online: 18 November 2010

(C) The Author(s) 2010. This article is published with open access at Springerlink.com

\begin{abstract}
To investigate the influence of black locust (Robinia pseudoacacia) flower and leaf fall on soil phosphate, we monitored litterfall, litter decomposition, and soil membrane phosphate in a $R$. pseudoacacia forest on Mt. Ilzasan, Seoul, Korea. $R$. pseudoacacia flower litter was $30-50 \%$ of total litter production in May and the flowers decomposed rapidly. More than $11 \%$ of $R$. pseudoacacia leaf litter decomposed from February to May, while that of Quercus spp. decomposed very little. Fast decomposition of $R$. pseudoacacia flower and leaf litter significantly increased membrane phosphate in the soil. The rapid nutrient-cycling of $R$. pseudoacacia through flower litterfall and rapid decomposition benefits the plant itself in the growing season when nutrients demand is increasing. Rapid nutrient-cycling might be a strategy that helps $R$. pseudoacacia to persist in poor soil environments.
\end{abstract}

Keywords Anion exchange resin membrane . Decomposition · Litterfall · Membrane phosphate .

Nutrient-cycling $\cdot$ Robinia pseudoacacia

Responsible Editor: Harry Olde Venterink.

Yong Chul Lee and Jong Min Nam have contributed equally.

Y. C. Lee · J. M. Nam•J. G. Kim $(\bowtie)$

Department of Biology Education, Seoul National

University,

Seoul 151-748, South Korea

e-mail: jaegkim@snu.ac.kr

\section{Introduction}

Litter production in forest ecosystems varies with community type, tree density, tree age, and nutrient conditions, and is known to be affected by soil, temperature, precipitation, light, pests, and other environmental factors (Barbour et al. 1998). In general, when the forest reaches equilibrium, annual litter production is maintained at a constant level (Turner and Lambert 1986), but varies seasonally (Mitchell et al. 1986, Sharma and Ambasht 1987). More than half of annual net productivity is deposited as litter in forests (Barbour et al. 1998). Inflow and outflow of nutrients in forest is important for nutrient cycling and litterfall is clearly dominant among the aboveground components of net primary production (Bray and Gorham 1964, Kim and Chang 1989).

Litter decomposition is influenced by various environmental factors such as climate, soil, topography, decomposers, season, etc. (Chang et al. 1987). Most litters are biologically decomposed by soil microbes and bottom dwellers and litter decomposition rates vary with the physiochemical properties of soil and the climate, which affect the kinds and numbers of soil microbes and bottom dwellers (Swift et al. 1979, Yavitt and Fahey 1986). Precipitation is the most important environmental factor affecting litter decomposition (Fogel and Cromack 1977), and the chemical composition of the litter, especially the lignin: $\mathrm{N}, \mathrm{C}: \mathrm{N}, \mathrm{C}: \mathrm{P}, \mathrm{N}: \mathrm{P}$ ratios, also has important effects on its decomposition rate (Barbour et al. 1998, 
Day 1983, Furniss and Ferrar 1982). Litter chemical composition varies with plant species, season, and organ.

Litter is the food source for decomposers on the ground and decomposed nutrients are returned to the cycling pool (Lee and Son 2006). Litterfall and litter decomposition represent a major contribution to the carbon and nutrient inputs in a forest ecosystem (Kim et al. 2003, Lee et al. 2006), and are the basic processes that sustains forest ecosystems because litter supplies most important nutrients for plant growth (Berg and Agren 1984).

Robinia pseudoacacia is deciduous, flowers in spring and bears a heavy crop of pea flowers. This plant was introduced into Korea in the 1890's, originally for use as railroad ties. In the 1950's and 1970's, R. pseudoacacia was planted in low mountain areas to restore forests and to supply fuel (Han and Gong 2003) because this plant symbiotically fixes $\mathrm{N}$, grows rapidly (Boring and Swank 1984a) and can survive well in infertile soils. Also, this plant is important in honey production in Korea.

Nitrogen and phosphorus are most frequently the limiting nutrients in infertile soil (Salisbury and Ross 1992). R. pseudoacacia can overcome the Nlimited environments by living in symbiosis with the $\mathrm{N}$-fixing bacteria in its root nodules (Boring and Swank 1984b). On the other hand, the phosphorus content of soluble form in low-pH forest soil is very low because phosphorus combines with ferrous or aluminum at low $\mathrm{pH}$ and turns into insoluble form (Furihata et al. 1992). Soil pH is generally low in $R$. pseudoacacia forests. Therefore, $\mathrm{N}$ fixing $R$. pseudoacacia might have a higher $\mathrm{P}$ demand than non-fixers, and can mine the soil $\mathrm{P}$ pool. This suggests that phosphorus might be the most important element limiting the growth of $R$. pseudoacacia.

Phosphorus can be added to the soil via a few processes: dust input, pollen shed, and litter fall. The effects of pollen and litter on the nutrient budget are probably usually larger than that of dust. Pollen is intensively sheds for a period early in summer, and rapid cycling of pollen's nutrients plays an important role in supplying nutrients to the forest floor and promoting litter decomposition (Lee 1997). Most litter is produced in autumn and decomposes in summer in Korea (Kim and Chang 1989). Therefore, pollen can add phosphorus in the early growing season and litter in the mid-growing season.

Most research on nutrient cycling in forest ecosystems has focused on annual litter production and decomposition, while few studies have examined seasonal variation in nutrient cycling or the effects of non-leafy materials on soil nutrients (Facelli and Pickett 1991).

The purpose of this study is to investigate the effects of litterfall, flower and leaf falls, of $R$. pseudoacacia on nutrient cycling in the early growing season, focusing on phosphorus. Specific objectives are 1) to determine seasonal litter production using litter traps, 2) to determine the decomposing rate using litter bags, and 3) to monitor the phosphate in soil using anion exchange resin membranes. To confirm the effect of $R$. pseudoacasia litterfall on nutrient cycling, data were compared with those in Quercus communities.

\section{Method}

Study area

This study was conducted at Mt. Ilzasan $\left(37^{\circ} 31^{\prime} 27^{\prime \prime} \mathrm{N}\right.$, $127^{\circ} 09^{\prime} 05^{\prime \prime E}, 110 \mathrm{~m}$ a.s.l.) in Seoul, Korea (Fig. 1). Annual mean temperature of Seoul is $12.2^{\circ} \mathrm{C}$, and annual precipitation is $1344.3 \mathrm{~mm}$. About $60 \%$ of annual precipitation is concentrated in July and August.

R. pseudoacacia communities are distributed on the north slope of Mt. Ilzasan and Quercus communities are found on the south slope. We selected three sites of size $20 \times 20 \mathrm{~m}$ in $R$. pseudoacacia communities and three in Quercus communities. The three $R$. pseudoacacia community sites had different importance values (I.V. = relative density+relative coverage, Curtis and McIntosh 1951) for R. pseudoacasia: 163.7 at Site a, 105.2 at Site b and 84.3 at Site c (Table 1). Site b contained one $R$. pseudoacacia individual $>40 \mathrm{~cm} \mathrm{DBH}$ and Site c contained five, while Site a only contained five individuals with $\mathrm{DBH}<10 \mathrm{~cm}$. This indicates that dominance of $R$. pseudoacacia was highest in Site a, intermediate in Site $\mathrm{b}$ and lowest in Site c. The dominant species in the Quercus communities were Q. mongolica in Site 1 and Site 2 and Q. acutissima in Site 3. The importance values of the dominant species in Quercus 
Fig. 1 Location of the study area in Korea (a, b, c: R. pseudoacacia community research sites, 1 , 2, 3: Quercus community research sites)

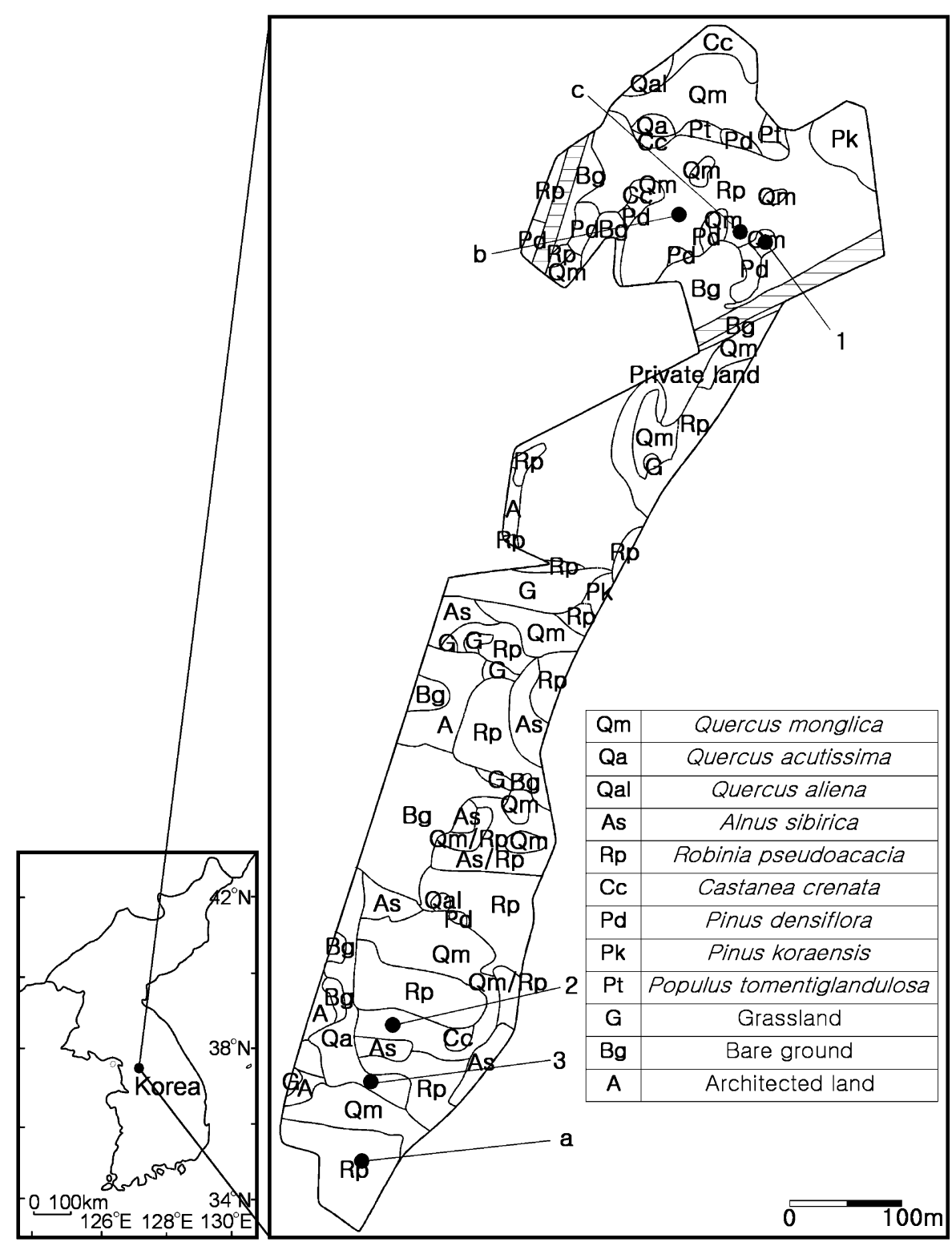

communities were 88.1 in Site 1, 76.4 in Site 2 and 169.5 in Site 3 (Table 1).

\section{Measuring litter production}

Two $1 \times 1 \mathrm{~m}$ litter traps were placed under the middle of dominant species trees in each site on December 17, 2008. Litterfall was collected at monthly intervals until November 2009 except in the winter and in the flowering season. Litterfall was collected on March 26, 2009 for the winter and on a weekly basis from
May 13 to June 18, which spanned the flowershedding event. All samples were sorted into flowers, leaves, and other plant organs, and dried at $80^{\circ} \mathrm{C}$ for $48 \mathrm{~h}$. Each fraction was weighed separately for each litter trap with an accuracy of $0.01 \mathrm{~g}$ (Scout Pro SPG202F, Ohaus Corporation, China).

Analysis of inorganic nutrients in flower fall and leaf fall of $R$. pseudoacacia

Flowers and leaves of $R$. pseudoacacia were collected immediately after they fell in spring or autumn. Litter 


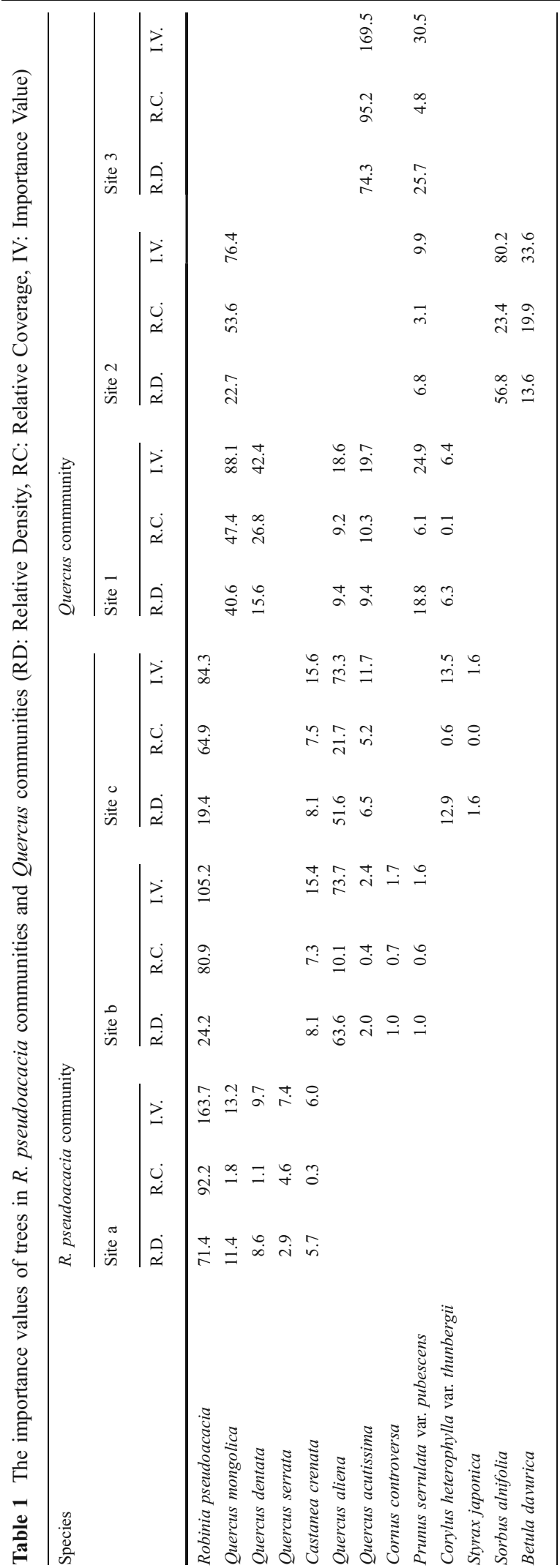

was dried at $80^{\circ} \mathrm{C}$ for $48 \mathrm{~h}$ immediately after collection. We milled the dried litter with a WILLY MINI-MILL (3380 L10, Thomas, USA) and then filtered it with 40 -mesh $(0.425 \mathrm{~mm})$. Total nitrogen (T-N) was determined using an Elemental Analyzer (Flash EA 1112, Thermo Electron, USA) and total phosphorus (T-P), potassium (K), calcium (Ca), magnesium $(\mathrm{Mg})$ and sodium $(\mathrm{Na})$ were measured using a Inductively Coupled Plasma Emission Spectrometer (ICPS-1000IV, Shimazu, Japan) after nitric acid digestion (Havlin and Soltanpour 1980) at the National Instrumentation Center for Environmental Management (NICEM) in Seoul National University.

Litter decomposition

The litter decomposition rate was measured using a litterbag method. Newly fallen leaf litter from two tree taxa (R. pseudoacacia and Quercus spp.) was collected on the forest floor on 25 November 2008. We filled $1-\mathrm{mm}$ mesh nylon litterbags $(20 \times 20 \mathrm{~cm})$ with $8.0 \mathrm{~g}$ of air-dried $R$. pseudoacacia leaf litter or $10.0 \mathrm{~g}$ of air-dried Quercus spp. leaf litter. Litterbags containing $R$. pseudoacacia leaf litter were placed in $R$. pseudoacacia community sites, and litterbags containing Quercus spp. litter were placed in both $R$. pseudoacacia and Quercus community sites on 17 February 2009. Four litterbags of each taxon were retrieved from each site at 100-day intervals. We used the decomposition model of Olson (1963) to calculate the annual decay constant (k) using the below equation.

$\mathrm{W}_{\mathrm{t}}=\mathrm{e}^{-\mathrm{kt}} \mathrm{W}_{0}$

(Wo: weight at time zero, $\mathrm{Wt}$ : weigh at time $\mathrm{t}$ (in years))

Membrane phosphate

Membrane phosphate was assessed using anion exchange resin (AER) strips (VWR ID No: 5516400, VWR International Ltd. Leics, England). The AER sheets were cut into $50 \times 20 \mathrm{~mm}$ strips. The AER strips were converted into $75 \%$ bicarbonate form and 25\% chloride form (Sibbesen 1978). A thin vertical slot was made in the soil A layer using a small steel bar of similar dimensions to the strip. The 
AER strip was placed into the slot without disturbing the soil any further (Bowatte et al. 2008). Twelve strips were installed at each site and the strips were replaced every 7 or 8 days from May 19 to October 15, 2009. Recovered strips were transferred in $50 \mathrm{~mL}$ polypropylene tubes containing $10 \mathrm{~mL}$ of phosphate reagent including ammonium paramolybdate, potassium antimony tartarate, sulphuric acid, and ascorbic acid (Saggar et al. 1990) and $40 \mathrm{~mL}$ of deionized water and the solution in the tubes was stirred several times over the course of $30 \mathrm{~min}$ until the blue color was fully developed. The concentration of phosphate was determined by the absorbance of the solution at a wavelength of $712 \mathrm{~nm}$ on a spectrophotometer.

\section{Data analyses}

SPSS for windows (version 15.0) was used for statistical analysis. To compare differences among sites, one way ANOVA and Duncan post hoc test were performed. Repeated measures ANOVA was conducted to compare data (membrane phosphate and litter decomposition) measured at several times. Litter decomposition in the repeated measures ANOVA used the ratio of the total weight remaining after 100, 200, 300 days.

\section{Results}

Production of litter

Litter production of $R$. pseudoacacia communities and Quercus communities showed two peaks, one in spring and one in autumn (Fig. 2). There was no statistical difference in the amount of annual litter production among the plant communities, but the flower production in $R$. pseudoacacia communities was significantly different among the communities. Flower fall account for considerable portion of the spring peak, while the autumn peak was mainly due to leaf fall.

The community structure at Site a differed from those at Site $\mathrm{b}$ and $\mathrm{c}$ (Table 1). The dominance of $R$. pseudoacacia was overwhelming at Site a but trees of Quercus spp., especially $Q$. aliena, had equal dominance to $R$. pseudoacacia at Site b and c. Therefore, the proportion of $R$. pseudoacacia in the litter was greater at Site a than at Site b and c.

R. pseudoacacia flower fall first appeared on May 13th, peaked on May 18th and 27th, and then declined drastically at Site b and c but remained high at Site a on June 3rd (Fig. 2). The proportion of flower fall from R. pseudoacacia in the total litter averaged $49.11 \%$ at Site a, $36.58 \%$ at Site b, and $30.81 \%$ at Site c from May to late June. In the Quercus communities, the
Fig. 2 Litter production in R. pseudoacacia communities and Quercus communities. a, b, c: $R$. pseudoacacia communities, Q: Quercus communities

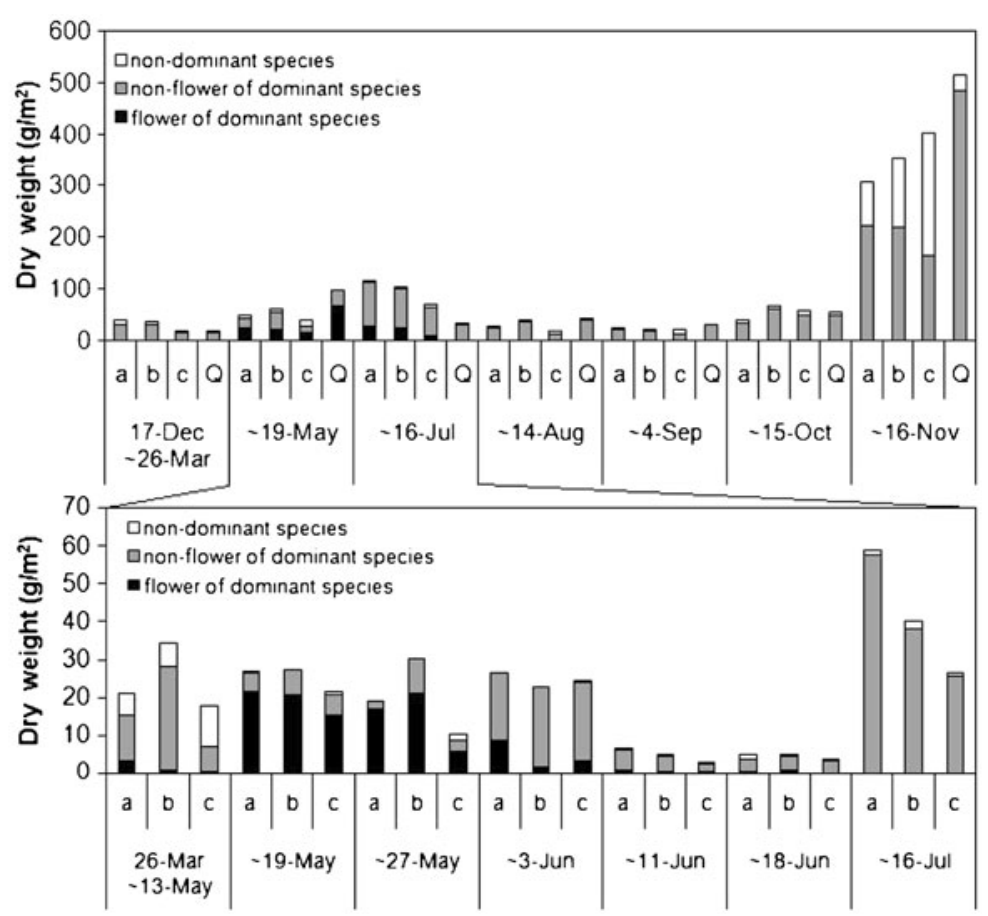


average proportion $(70.50 \%)$ of flower litter in the total litter from May to late June was larger than in the $R$. pseudoacacia community because fruits of $R$. pseudoacacia fall in spring, and leaflets fall little by little in spring and summer, but acorns and leaves of Quercus spp. rarely fall in spring.

Inorganic nutrients in flower fall and leaf fall of R. pseudoacacia

The concentrations of total nitrogen and phosphorus were significantly different between the flowers and the leaves of $R$. pseudoacacia (Table 2). The flowers of $R$. pseudoacacia had $4.04 \%$ of T-N, or twice as high as the concentration in leaves, and T-P concentration in flowers was about five times higher than in leaves. However, $\mathrm{Ca}$ and $\mathrm{Na}$ were lower in flowers than in leaves. That is, the flowers of $R$. pseudoacacia are rich in nitrogen and phosphorus.

\section{Decomposition of leaf litter}

The decay constant (k) of $R$. pseudoacacia leaf litter in $R$. pseudoacacia communities was 1.213 and the kvalues of Quercus spp. leaf litter in $R$. pseudoacacia communities and in Quercus communities were 1.191 and 1.043 , respectively.

R. pseudoacacia leaf litter lost $11.15 \%$ of its mass from 17 February to 20 May in $R$. pseudoacacia communities, and Quercus spp. leaf litters lost $4.44 \%$ and $0.91 \%$ of their masses in R. pseudoacacia and Quercus communities, respectively (Fig. 3). Repeated measures ANOVA showed that there was a highly

Table 2 Inorganic nutrients in fallen $R$. pseudoacacia flowers and leaves (T-N: total nitrogen, T-P: total phosphorus, Average $\pm 1 \mathrm{SD}, n=4)$

\begin{tabular}{lcr}
\hline & \multicolumn{1}{l}{ Flower } & \multicolumn{1}{l}{ Leaf } \\
\hline $\mathrm{T}-\mathrm{N}(\mathrm{mg} / \mathrm{g})^{*}$ & $40.44 \pm 10.88$ & $19.92 \pm 2.76$ \\
$\mathrm{~T}-\mathrm{P}(\mathrm{mg} / \mathrm{g})^{*}$ & $3.30 \pm 0.21$ & $0.63 \pm 0.09$ \\
$\mathrm{~K}(\mathrm{mg} / \mathrm{g})$ & $17.49 \pm 0.86$ & $10.97 \pm 3.32$ \\
$\mathrm{Ca}(\mathrm{mg} / \mathrm{g})^{*}$ & $2.30 \pm 1.20$ & $19.72 \pm 0.73$ \\
$\mathrm{Mg}(\mathrm{mg} / \mathrm{g})^{*}$ & $0.95 \pm 0.27$ & $0.80 \pm 0.17$ \\
$\mathrm{Na}(\mathrm{mg} / \mathrm{g})^{*}$ & $0.05 \pm 0.01$ & $0.29 \pm 0.05$ \\
\hline
\end{tabular}

*indicates significant difference between two groups based on t-test, $p<0.05$

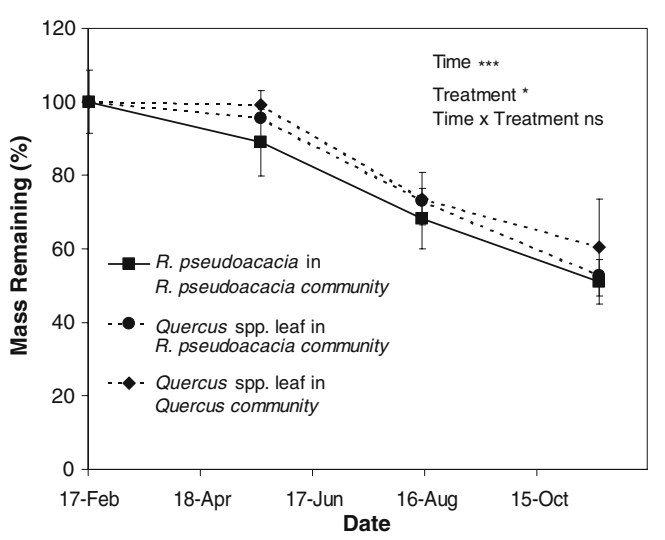

Fig. 3 Percentage of remaining dry mass during a nine-month litterbag study. The interval between recovered dates was about 90 days. Bar indicates 1 Standard Error $(n=4)$. Significance of main effects of treatment and time are noted as $* * * p<0.001 ;{ }^{*} p<$ 0.05 ; ns not significant

significant main-effect of date $\left(\mathrm{F}_{2}, 50=145.3, p<\right.$ $0.0001)$ and the mass loss was significantly different among the communities $\left(\mathrm{F}_{2,25}=3.9, p=0.034\right)$. The decomposition of $R$. pseudoacacia litter started earlier than that of Quercus spp. litter and the mass loss rate of R. pseudoacacia leaf litter from May to August was faster than that of Quercus spp. leaf litter. Quercus spp. leaf litter decomposed faster in $R$. pseudoacacia communities than in Quercus communities.

Membrane phosphate in soil

Mauchly's test of sphericity was highly significant $(p<$ 0.0001 ), and therepeated measures ANOVA with Huynh-Feldt correction was used. The factor 'Sampling date' had significant difference $\left(\mathrm{F}_{55.7}, 4.6=3.9, p=\right.$ $0.005)$ and there were significant interactions between sampling date and sites $\left(\mathrm{F}_{55.7,13.9}=2.0, p=0.032\right)$. Membrane phosphate in soil was significantly different among the sites $\left(\mathrm{F}_{3,12}=7.5, p=0.004\right)$, and post hoc tests showed that membrane phosphate in the soil was significantly higher in $R$. pseudoacacia communities than in Quercus communities during most of the study period $(p<0.05)$. Among the study sites, the membrane phosphate was highest in Site a (Fig. 4), which had the highest relative density and coverage of $R$. pseudoacacia (Table 1).

The pattern of change in membrane phosphate in the soil was similar to that of precipitation (Fig. 4). From 11 June to 18 June, there was no precipitation and membrane phosphate was very low in all communities. Except for this week, however, mem- 


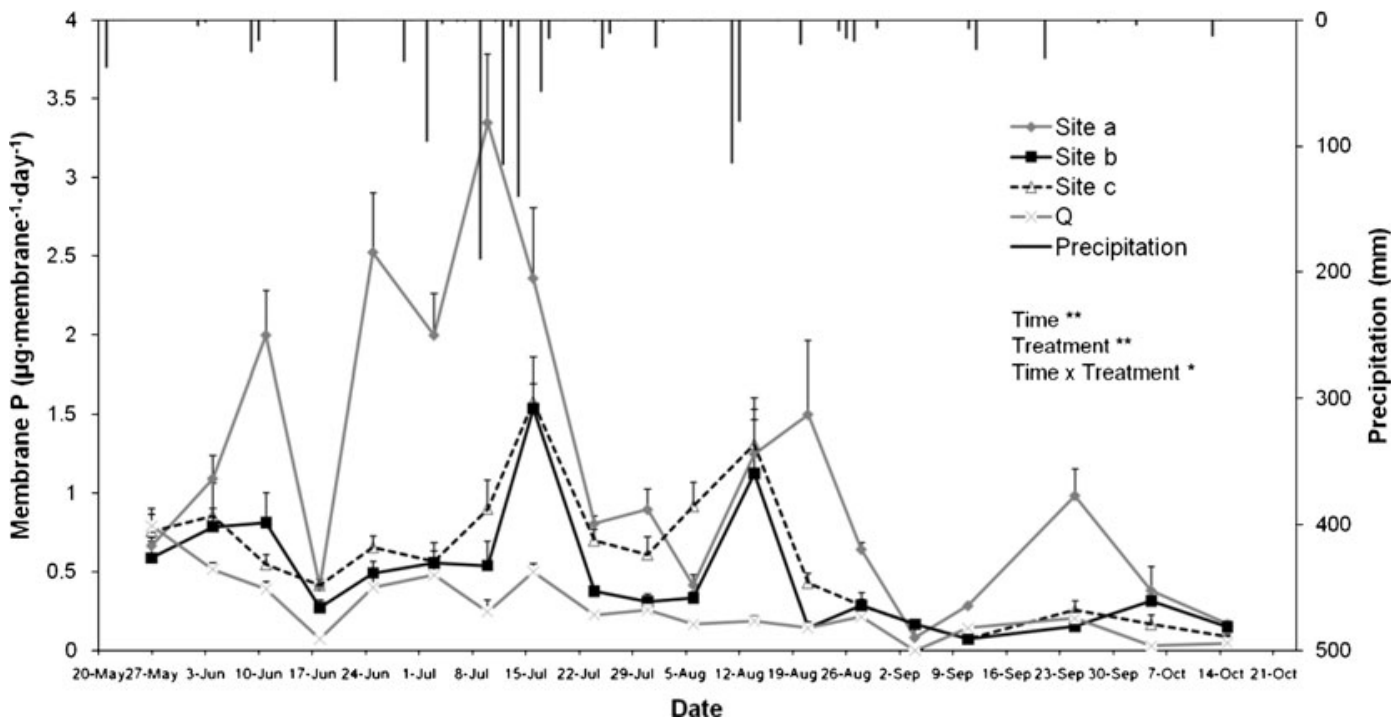

Fig. 4 Changes in membrane phosphate in soil and precipitation. (Site a, Site b, Site c: $R$. pseudoacacia communities, Q: Quercus communities). Bar at data points of phosphorus

brane phosphate in $R$. pseudoacacia communities increased (Site a) or remained steady (Site b and c) from May to June in R. pseudoacacia communities, but not in Quercus communities.

\section{Discussion}

The difference of the phenology according to plant species can affect the production of litter fall. The litter fall during the growing period is noticeable from an aspect of nutrient cycling although most of litter fall happen in autumn. Thus, the early litterfall of $R$. pseudoacacia during the period from mid-May to mid-June have a potential as nutrient sources during the rapid growing season when nutritional demands are increasing. In particular, the amount of flower fall in $R$. pseudoacacia communities exceeded the leaf fall during the flowering season. In addition, the flowers are more nutritional than the leaves in that nutrients necessary for plant growth, such as $\mathrm{N}, \mathrm{P}$, and $\mathrm{K}$, are more abundant in the flowers.

Rim (1981) reported that most flowers are not only rich in $\mathrm{P}$ and $\mathrm{N}$, but the decomposition rate is also generally high. The flowers of $R$. pseudoacacia fell on the forest floor intensively from 13 to 27 May and were not observed any more with naked eye on the forest floor since 11 June. This fact suggests that the indicates 1 Standard Error $(n=12)$. Significance of main effects of treatment and time are noted as $* * p<0.01 ;{ }^{*} p<0.05$

flowers of $R$. pseudoacacia were assumed to be decomposed within 2 weeks. Therefore, highly nutritious flowers of $R$. pseudoacacia can support the plant growth through rapid decomposition, suggesting that rapid nutrient cycling might occur in $R$. pseudoacacia communities in the growing season.

The nutrients in the rapidly decomposed leaves can be used as nutrient sources by vigorous plants. Thus, the extent of the leaf decomposition can be important in nutrient cycling. The decomposition of the leaf litter was highest in the period from May to August within this study period. Previous studies also reported that the decomposition in litter bags increased in the summer (Kim 2003, Yang and Shim 2003), and especially from July to August, when the precipitation in Korea is high (Kim and Chang 1989). White et al. (1988) reported that $R$. pseudoacacia leaf litters decompose rapidly in a year and then decompose very slowly.

The leaf decomposition can also depend on the shape of leaves (Barbour et al. 1998). And compound leaves provide much greater edge surface area for attack by decomposers. Thus, being pinnately compound and soft, the leaves of R. pseudoacacia can be vulnerable to the decomposition. Although the decomposition rate can vary with the environmental characteristics of the study area (Tateno et al. 2007), the decomposition rate of $R$. pseudoacacia leaves in 
this study using litter bag method was higher than the rate measured by using the annual production of the organic carbon in litters and the amount of the accumulated organic carbon on the forest floor in another study (Kim and Chang 1997). And the decomposition of $R$. pseudoacacia leaves in their own communities was faster than that of Quercus leaves in their own communities, indicating the rapid decomposition of $R$. pseudoacacia leaf in summer season.

In addition, Quercus spp. leaf litter decomposed faster in $R$. pseudoacacia communities than in Quercus communities. Mixed-species litter was reported to decompose faster than single-species litter (Gartner and Cardon 2004). Thus, we can suppose that the proliferation of decomposers in the $R$. pseudoacacia leaves being decomposed may also accelerate the decomposition of Quercus leaves in $R$. pseudoacacia communities. And the early decomposition of leaf litter in $R$. pseudoacacia communities during the growing season can also supply significant nutrition for the plant community.

The membrane phosphate in soil was relatively higher in $R$. pseudoacacia communities than in $Q$. mongolica communities, and in particular, the site where $R$. pseudoacacia were definitely dominant in the density and coverage had remarkably higher concentration of membrane phosphate (Fig. 4). Chang et al. (1987) also found that the amounts of phosphorus returned to soil annually in $R$. pseudoacacia forests are greater than those in $Q$. mongolica forests. Therefore, the increased adsorption of phosphate to the membranes in the soil can be caused by the rapid decomposition of leaves and flowers. In particular, the input of the phosphorus-abundant and rapidlydecomposable flowers may promote phosphorus cycling during the initial growing season, the period from the end of May to early in June (Figs. 2 and 4).

In addition to the decomposed litter fall, the precipitation also seemed to influence the increased adsorption of phosphate to the membranes in the soil in this study (Fig. 4). This can be explained by the change of phosphate mobility. That is, the increased precipitation can promote the movement of phosphate in soil and then, the adsorption of phosphate to the membranes in the soil can be raised. However, even after taking the effect of the precipitation into consideration, the increased adsorption of phosphate to the membranes in the soil was more distinguished in $R$. pseudoacacia communities. This suggests that the mobility of phosphate in soil tend to be higher in $R$. pseudoacacia communities than in $Q$. mongolica communities. In conclusion, we can suggest that the litter fall of $R$. pseudoacacia, specifically the fallen flowers and their rapid decomposition support the rapid cycling of nutrient such as phosphorus in $R$. pseudoacacia communities.

Synthesis The proportion of $R$. pseudoacacia flower fall in the total litter was high in the period from May to late June. $R$. pseudoacacia flowers contain more phosphorus than leaves and rapid decomposition of $R$. pseudoacacia flowers increases the phosphorus availability in the soil in the early growing season when the nutrient demand is increasing. In addition, $R$. pseudoacacia leaf fall decomposes faster than Quercus spp. leaf fall and thus increase of dissolved phosphate by rapid decomposition of leaves causes more increase of phosphorus in $R$. pseudoacacia communities than in Quercus communities. Our results show that phosphorus circulates more rapidly in $R$. pseudoacacia communities than in Quercus communities. Rapid phosphorus cycling and uptake of nitrogen through symbiosis with legume bacteria help R. pseudoacacia to grow well in infertile soil.

Acknowledgements We would like to thank Professors E Rejmankova (UC Davis), S Lappan (Appalachian State University), PS Park (Seoul National University), H Olde Venterink and two anonymous reviewers for valuable comments in improving the manuscript. We also appreciate for the help of HB Kim for assistance in purchasing an anion exchange resin sheet. We thank $\mathrm{H}$ Choi for helping with the community analysis, $\mathrm{H} \mathrm{Kim}$ for helping with the data analysis and editing the manuscript, KM Lee, SJ Min, JS Choi and YH Lee for helping with recovery of AER strips and collection of litterfall. Finally, we would like to express our gratitude to Ms. S Chung at Statistical Research Institute of Seoul National University for statistical consulting.

Open Access This article is distributed under the terms of the Creative Commons Attribution Noncommercial License which permits any noncommercial use, distribution, and reproduction in any medium, provided the original author(s) and source are credited.

\section{References}

Barbour MG, Burk JH, Pitts WD, Gilliam FS, Schwartz MW (1998) Terrestrial plant ecology, 3rd edn. Addison Wesley Longman, New York 
Berg B, Agren G (1984) Decomposition of needle litter and its organic chemical components: theory and field experiments. Long-term decomposition in a Scots pine forest III. Can J Bot 62:2880-2888

Boring LR, Swank WT (1984a) Symbiotic nitrogen fixation in regenerating Black locust (Robinia pseudoacacia L) stands. For Sci 30:528-537

Boring LR, Swank WT (1984b) The role of Black locust (Robinia pseudoacacia) in forest succession. J Ecol 72:749-766

Bowatte S, Tillman R, Carren A, Gillinghan A, Scotter D (2008) In situ ion exchange resin membrane(IEM) technique to measure soil mineral nitrogen dynamics in grazed pastures. Biol Fertil Soils 44:805-813

Bray JR, Gorham E (1964) Litter production in forest of the world. Adv Ecol Res 2:101-187

Chang NK, Lee SK, Lee BS, Kim HB (1987) The decay map and turnover cycles of litters in Korea. Korean $\mathrm{J}$ Ecol 10:183-193, in Korean

Curtis JT, McIntosh RP (1951) An upland forest continuum in the Prairie forest border region of Wisconsin. J Ecol 32:476-496

Day FP (1983) Effects of flooding on leaf litter decomposition in microcosms. Oecologia 56:180-184

Facelli JM, Pickett STA (1991) Plant litter: Its dynamics and effects on plant community structure. Bot Rev 57:1-32

Fogel R, Cromack KJ (1977) Effect of habitat and substrate quality on Douglas fir litter decomposition in Western Oregon. Can J Bot 55:1632-1640

Furihata T, Suzuki M, Sakurai H (1992) Kinetic characterization of two phosphate uptake systems with different affinities in suspension-cultured Catharanthus roseus protoplasts. Plant Cell Physiol 33:1151-1157

Furniss PR, Ferrar P (1982) A model of savanna litter decomposition. Ecol Model 17:33-51

Gartner TB, Cardon ZG (2004) Decomposition dynamics in mixed-species leaf litter. Oikos 104:230-246

Han HJ, Gong WS (2003) The geographical distribution of naturalized plants and artificial factor: Focused on $R$. pseudoacacia. In: Proceedings of 2003 annual meeting for The Korean Geographical Society, pp. 129-132 (in Korean)

Havlin JL, Soltanpour PN (1980) A nitric acid plant tissue digest method for use with inductively coupled plasma spectrometry. Commun Soil Sci Plant Anal 11:969-980

Kim CS (2003) Mass loss rate and nutrient dynamics of oak and mixed-hardwood leaf litters in a Gyebangsan (Mt.) forest ecosystem. Korean J Ecol 26:335-340, in Korean

Kim JG, Chang NK (1989) Litter production and decomposition in the Pinus rigida plantation in Mt. Kwan-ak. Korean J Ecol 12:9-20 (in Korean)

Kim JH, Chang NK (1997) A study on the production and decomposition of litters of major forest trees in Korea. Korean Turfgrass Sci 11:33-43, in Korean

Kim CS, Lim JH, Shin JH (2003) Nutrient dynamics in litterfall and decomposing leaf litter at the Kwangneung deciduous broad-leaved natural forest. Korean J Agri For Meteorol 5:87-93 (in Korean)

Lee EJ (1997) Importance of pollen rain in boreal Manitoba, Canada. Univ Manitoba Ph.D dissertation

Lee IK, Son YH (2006) Effects of nitrogen and phosphorus fertilization on nutrient dynamics and litterfall production of Pinus rigida and Larix kaempferi. J Ecol Field Biol 29:205-212

Lee IK, Lim JH, Kim CS, Kim YK (2006) Nutrient dynamics in decomposing leaf litter and litter production at the Long-Term Ecological Research Site in Mt. Gyebangsan. J Ecol Field Biol 29:585-591

Mitchell DT, Coley PGF, Webb S, Allsopp N (1986) Litterfall and decomposition processes in coastal Fynbos vegetation, southwestern Cape, South Africa. J Ecol 74:977-993

Olson JS (1963) Energy storage and the balance of producers and decomposers in ecological systems. Ecology 44:322331

Rim YD (1981) Studies on the nutrient circulation in the forest ecosystem 1. On the decomposition of sexual organ of Salix babylonica. Korean J Ecol 4:33-37

Saggar S, Hedley MJ, White RE (1990) A simplified resin membrane technique for extracting phosphorus from soils. Fertil Res 24:173-180

Salisbury FB, Ross CW (1992) Plant physiology, 4th edn. Wadsworth Inc, California, p 131

Sharma E, Ambasht R (1987) Litterfall, decomposition and nutrient release in an age sequence of Alnus nepalensis plantation stands in the eastern Himalaya. J Ecol 75:9971010

Sibbesen E (1978) An investigation of the anion-exchange resin method for soil phosphate extraction. Plant Soil 50:305321

Swift MJ, Heal OW, Anderson JM (1979) Decomposition in terrestrial ecosystems. University of California Press p. 372

Tateno R, Tokuchi N, Yamanaka N, Du S, Otsuki K, Shimamura T, Xue Z, Wan SQ, Hou QC (2007) Comparison of litterfall production and leaf litter decomposition between an exotic black locust plantation and an indigenous oak forest near Yan'an on the Loess Plateau, China. For Ecol Manage 241:84-90

Turner J, Lambert MJ (1986) Nutrition and nutritional relationships of Pinus radiata. Ann Rev Ecol Syst 17:325-350

White DL, Haines BL, Boring LR (1988) Litter decomposition in southern Appalachian black locust and pine-hardwood stands: litter quality and nitrogen dynamics. Can J For Res 18:54-63

Yang KC, Shim JK (2003) The decomposition of leaf litters of some tree species in temperate deciduous forest in Korea. I. Losses in dry weight of leaf litter. Korean $\mathrm{J}$ Ecol 26:203-208 (in Korean)

Yavitt JB, Fahey TJ (1986) Litter decay and leaching from the forest floor in Pinus contorta (Lodgepole pine) ecosystems. J Ecol 74:525-545 